\title{
Optimization model of electrification ratio using solar photovoltaic: case study in Kupang Regency
}

\author{
Rusman Sinaga ${ }^{1, *}$ Armansyah H.Tambunan ${ }^{2}$, Prastowo ${ }^{2}$, Bintang C.H. Simangunsong ${ }^{2}$ \\ ${ }^{1}$ State Polytechnic of Kupang, Po.Box.139, Penfui. Kupang 85361, Indonesia \\ ${ }^{1,2}$ Graduate School, Bogor Agricultural University, Po.Box. 220. Darmaga. Bogor 16680, Indonesia
}

\begin{abstract}
The Electrification ratio in Indonesia is $89.10 \%$, which means there are 7, 245,728 of 66, 489,400 households don't have access to Electrical Energy Sources (EES). Kupang Regency is one of the Regency in Indonesia which has a low electrification ratio. 29,542 of 78,109 households haven't access to EES spread over 29 villages (electrification ratio of $62 \%$ ). Solar Photovoltaic in Kupang Regency 5 MWp capacity has been operating but directly connected (On-Grid) to the State Electricity Company (PLN), it is not able to help rural communities that are difficulties to reach due to its geographical conditions. The aim of this research was design the electrification ratio optimization model with the consideration of $\mathrm{CO}_{2}$ emission reduction using Solar Photovoltaic. The method of research using dynamic modeling approach. The result of the research shows that electrification ratio can be achieved optimum estimated in 2020-2021 if the addition of capable power each year $4,000 \mathrm{~kW}$. The addition of capable power 2,000 kW/year, can reach the optimum electrification ratio in 2023-2024 and if the addition of capable power is only 1,000 $\mathrm{kW} /$ year, the optimum electrification ratio can be achieved in 2030-2031. Diversification of DPG into Solar PV can reduce $\mathrm{CO}_{2}$ emissions by $98.8 \%$.
\end{abstract}

Keywords : Solar Photovoltaic, electrification, $\mathrm{CO}_{2}$ emissions, Kupang Regency, Model

\section{INTRODUCTION}

Electrical Energy is one form the energy most commonly used in the modern world, that can be easily converted into other forms of energy and can safely and efficiently be distributed over the distance. Electricity is required in almost every stage of economic activity from the upstream to downstream as to the operation of household appliances, information and communication equipment, education equipment, medical equipment, woodworking equipment, lighting, electrical machinery for driving such as water pumps, cooling machine, electric heating and others [1]. Electricity will affect the development of the economy and society welfare.

The current electrification ratio in Indonesia is $89.10 \%$. The number of households that do not have access to EES is 7, 245,728 of 66, 489,400. Some provinces even have electrification ratios below $60 \%$, such as Jambi, West Sulawesi, West Papua and East Nusa Tenggara (ENT) due to lack of electricity infrastructure. The State Electricity Company of Indonesia (PLN) for East Nusa Tenggara region noted that there are 535,418 out of 1, 126,400 households in ENT Province have no access to EES with electrification ratio of $52.47 \%$ [2]. Meanwhile, Central Bureau of Statistics of Kupang Regency [3], noted that there are 29,542 of 78,109 households in 29 of the 177 villages in Kupang Regency ENT Province have no access to EES (electrification ratio is 62\%). On the other hand, in line with Paris agreement, 
Indonesia has expressed its commitment to reduce Greenhouse Gas (GHG) emissions by $29 \%$ on its own efforts, or $41 \%$ with International support, by the year 2030 [4], [5]. Indonesia commitment in Paris agreement will be difficult to achieve If electricity production for increasing the electrification ratio is accomplished by using fossil energy sources.

Indonesia lies on the equator and has a tropical climate so that the solar energy received is very abundant that can be utilized as an alternative in overcoming the energy crisis and decrease $\mathrm{CO}_{2}$ emissions. Rahardjo \& Fitriana [6] has studied the potential of solar energy resources by concluding that the average solar radiation intensity in East Nusa Tenggara is $5,117 \mathrm{Wh} / \mathrm{m}^{2} /$ day, which has the potential to generate electrical energy. This study is supported by research Sinaga [7] on the effect of environmental parameters on the output of Solar PV in Kupang Regency. This study concludes that in the morning, noon and afternoon Illumination of sunlight rays affect the energy output on the Solar Photovoltaic, If Illumination increases $1 \mathrm{Lux}$ then the energy output will increase $0.001 \mathrm{Wh}$. During the day Temperature effect on the energy output on the Solar PV, If Temperature increases 1 degree then the power output of Solar PV will increase $0.121 \mathrm{Wh}$.

\section{METHODOLOGY}

This research was designed with system approach method using the dynamic models [8]-[11]. The dynamic model used in this research to model the production of electricity using Solar Photovoltaic (Solar PV) compared to the Diesel Power Generation (DPG) for optimizing the electrification ratio and with the consideration of $\mathrm{CO}_{2}$ emission reduction. The methods of data collection are done by literature study, survey, observation and compilation of reports.

Emission Factor Analysis (EFA) was done by calculating $\mathrm{CO}_{2}$ emissions using Tier 1 at IPCC as follows:

1) Calculating the amount of electrical energy generated at the power plant per year by using equation (1) [12]:

$$
E_{\text {elect }}=C P \times t
$$

Where, $E_{\text {elect }}$ is electrical energy generated in a year $(\mathrm{kWh}), C P$ is capable power $(\mathrm{kW})$, and $t$ is effective working time in a year $(\mathrm{h})$.

2) Calculating $\mathrm{CO}_{2}$ emissions using equation (2) [13] :

$e_{\mathrm{CO} 2}=E_{\text {elect }} \times E F$

Where $e_{\mathrm{CO} 2}$ is $\mathrm{CO}_{2}$ emissions (ton), and $E F$ is emission factor (ton/kWh). The $\mathrm{CO}_{2}$ EF for DPG has been established by UNDP empirically is $0.786 \mathrm{Kg} / \mathrm{kWh}$ [14] and $\mathrm{CO}_{2} \mathrm{EF}$ for Solar PV is $0.0094 \mathrm{Kg} / \mathrm{kWh}$ [15]

The electrification ratio is the ratio of the electrified household to the number of households [16].

\section{ANALYSIS AND DISCUSSION}

Table 1 show the condition of electrification in Kupang Regency, which is processed from the statistical data of the Central Bureau of Statistics of Kupang Regency for the sub-district. The table shows that 9 out of 24 sub-district have 
electrification ratio less than $50 \%$, as many as 29,542 households do not have access to electrical energy sources, which is about $38 \%$ of the total number of households making electrification ratio of Kupang Regency to become 62\%. 29 villages from 9 sub-districts do not have access to PLN's electricity source.

The Solar PV Off-Grid is designed to produce electrical energy that can be stored in the battery so that stored energy can be used both at night and during the day. DPG is the Power Generation designed to produce electrical energy using diesel fuel oil as primary energy source. Both types of power plants can be used in remote areas far from PLN's power grid to raise the elctrification ratio, but both have different characteristics. In this study, the difference is shown in the design of optimizing the electrification ratio by considering the decrease in $\mathrm{CO}_{2}$ emissions as illustrated by the stock-flow diagram in Fig.1.

Table 1 Electrification condition in Kupang Regency

\begin{tabular}{|c|c|c|c|c|c|c|c|c|c|}
\hline Nr. & Sub-District & NV & $V n E$ & $H P$ & $H n P$ & $H n E$ & $\mathrm{NH}$ & $E R(\%)$ & $\mathrm{S}$ \\
\hline 1 & Amabi Oefeto & 7 & - & 1.691 & 75 & 233 & 1.999 & 85 & {$[17]$} \\
\hline 2 & Amabi Oefeto Timur & 10 & - & 2.749 & - & 778 & 3.527 & 78 & [18] \\
\hline 3 & Amarasi & 9 & - & 3.836 & 196 & - & 4.032 & 95 & [19] \\
\hline 4 & Amarasi Barat & 8 & - & 2.678 & 747 & 1.321 & 4.746 & 56 & [20] \\
\hline 5 & Amarasi Selatan & 5 & - & 2.265 & 51 & 185 & 2.501 & 91 & [21] \\
\hline 6 & Amarasi Timur & 4 & - & 1.750 & 106 & 187 & 2.043 & 86 & [22] \\
\hline 7 & Amfoang Barat Daya & 4 & 1 & 202 & 796 & 15 & 1.013 & 20 & [23] \\
\hline 8 & Amfoang Barat Laut & 6 & 5 & 32 & 750 & 869 & 1.651 & 2 & [24] \\
\hline 9 & Amfoang Selatan & 7 & - & 685 & 344 & 758 & 1.787 & 38 & [25] \\
\hline 10 & Amfoang Tengah & 4 & 2 & 98 & 123 & 778 & 999 & 10 & [26] \\
\hline 11 & Amfoang Timur & 5 & 4 & 20 & 455 & 800 & 1.275 & 2 & [27] \\
\hline 12 & Amfoang Utara & 6 & 3 & 567 & 90 & 240 & 897 & 63 & [28] \\
\hline 13 & Fatuleu & 10 & 3 & 1.897 & 551 & 3.776 & 6.224 & 30 & [29] \\
\hline 14 & Fatuleu Barat & 5 & 5 & 0 & 710 & 1.571 & 2.281 & $\mathbf{0}$ & [30] \\
\hline 15 & Fatuleu Tengah & 4 & - & 550 & 80 & 667 & 1.297 & 42 & [31] \\
\hline 16 & Kupang Barat & 12 & - & 3.699 & 48 & 209 & 3.956 & 94 & [32] \\
\hline 17 & Kupang Tengah & 8 & - & 7.545 & 655 & 794 & 8.994 & 84 & [33] \\
\hline 18 & Kupang Timur & 13 & - & 6.830 & 472 & 2.905 & 10.207 & 67 & [34] \\
\hline 19 & Nekamese & 11 & - & 2.182 & 236 & 93 & 2.511 & 87 & [35] \\
\hline 20 & Semau & 8 & - & 1.395 & - & 287 & 1.682 & 83 & [36] \\
\hline 21 & Semau Selatan & 6 & - & 1.167 & 10 & 172 & 1.349 & 87 & [37] \\
\hline 22 & Sulamu & 7 & 1 & 2.506 & 11 & 1.384 & 3.901 & 64 & [38] \\
\hline 23 & Taebenu & 8 & - & 2.993 & 208 & 580 & 3.781 & 79 & [39] \\
\hline 24 & Takari & 10 & 5 & 1.230 & 1.160 & 3.066 & 5.456 & 23 & [40] \\
\hline & Jumlah & 177 & 29 & 48.567 & 7.874 & 21.668 & 78.109 & 62 & \\
\hline
\end{tabular}

Remark: NV: Number of Villages, VnE: Number of villages without electrification, HP: Number of households has been electrified from PLN, HnP: Number of households were not electrified from PLN, HnE: Number of households were not electrified, ER: Electrification Ratio, NF: Number of households, $S$ :Sources. 


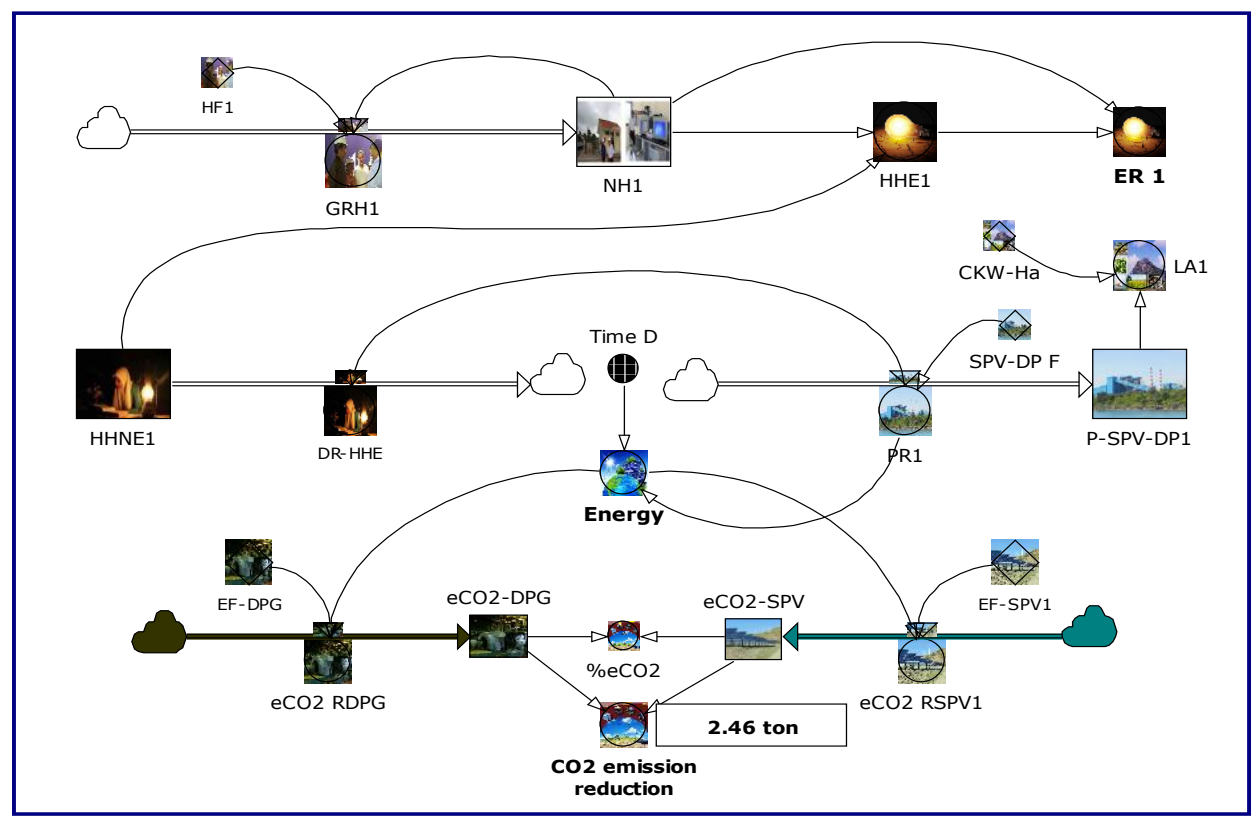

Fig. 1. Stock-flow diagram of optimization electrification ratio in Kupang Regency

The modeling of electrification ratio optimization in this study uses three scenarios of two types of power generation (Solar PV and DPG), namely: the first scenario uses 1,000 kW capable power, the second scenario uses $2,000 \mathrm{~kW}$ capable power and the third scenario uses $4,000 \mathrm{~kW}$ capable power. The assumption is that every household uses the tariff $\mathrm{R} 1=$ $450 \mathrm{~W}$. The results show that in the first scenario, the electrification ratio reaches an optimum (100\%) estimated in 2030-2031, while in the second scenario, the electrification ratio is estimated to be optimal in 2023- 2024 and in the third scenario it is estimated that the electrification ratio reaches optimum in 2020-2021. The comparison of the electrification ratio of the three scenarios is presented in Fig. 2.

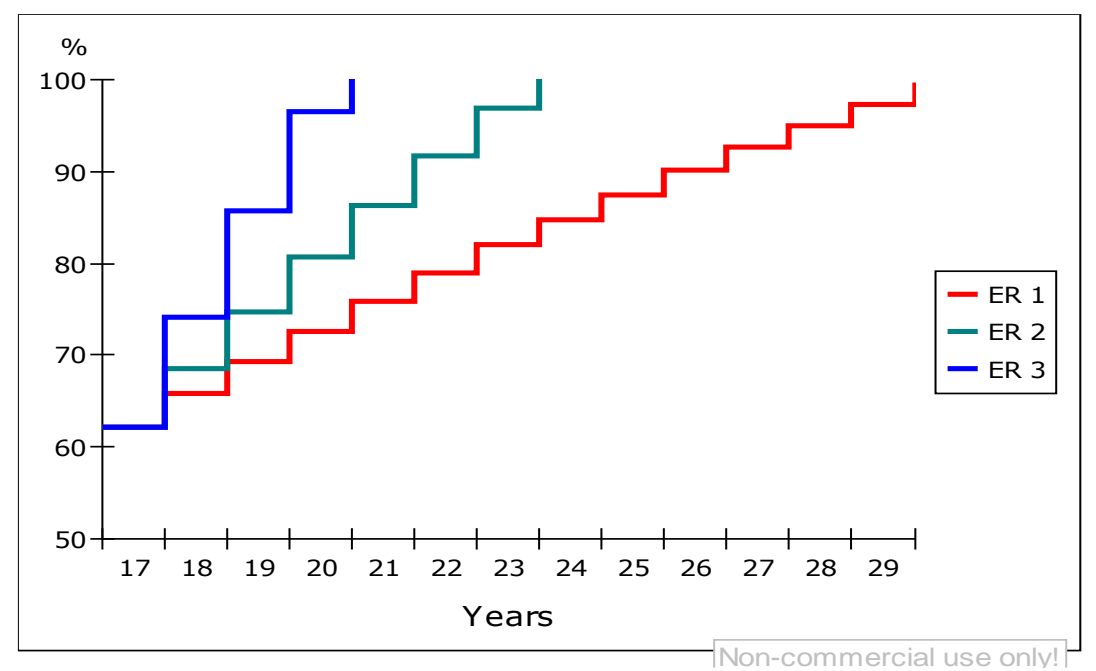

Fig. 2. Comparison of electrification ratios for 1, 2 and 3 scenarios 
The number of $\mathrm{CO}_{2}$ emissions produced for optimizing the electrification ratio using the DPG in the first scenario is 38,041 tons, the second scenario 35,115 tons and the third scenario 35,115 tons. If using Solar PV, then the estimated $\mathrm{CO}_{2}$ emissions for the first scenario is 455 tons, the second scenario is 420 tons and the third scenario is 420 tons. Diversification of DPG into Solar PV can reduce $\mathrm{CO}_{2}$ emissions by $98.8 \%$. The simulation of $\mathrm{CO}_{2}$ emission ratio of DPG with Solar PV is presented in Fig. 3.

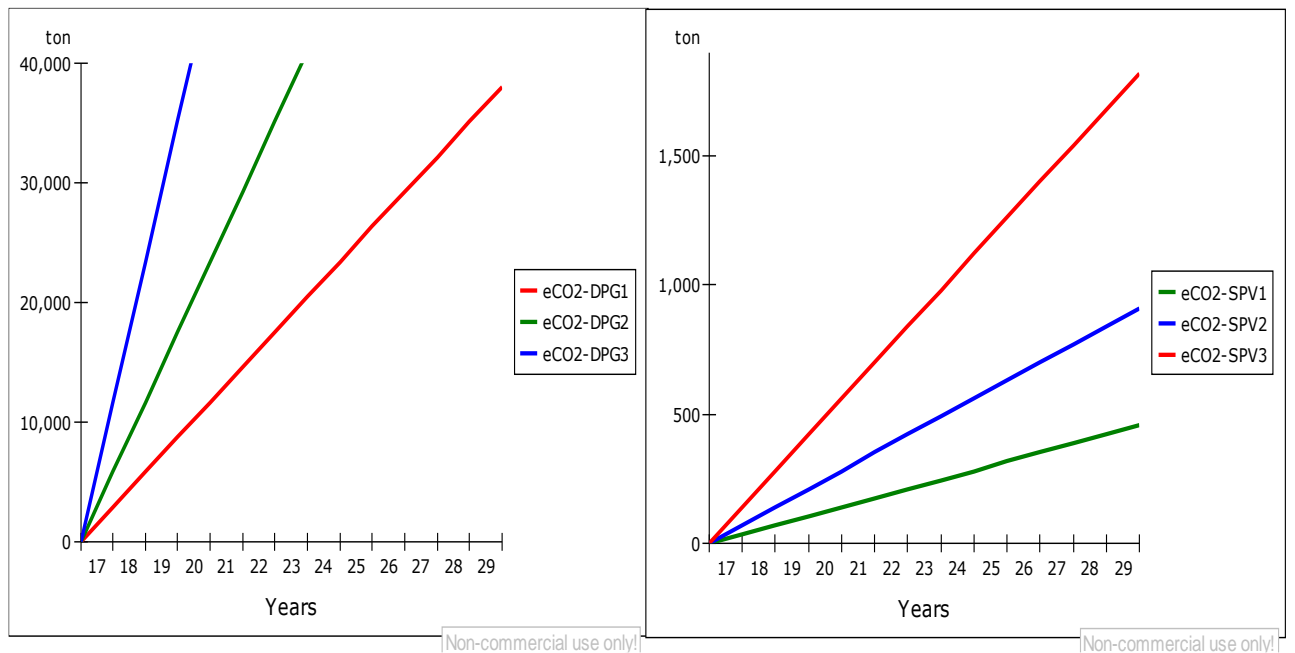

Fig. 3. Simulate the amount of $\mathrm{CO}_{2}$ emissions by using Solar PV and DPG

The current number of households in Kupang Regency is 78,109, with the fraction of household growth $2.35 \%$ / year, the estimated number of households in 2030 is 105,643. The addition of electrical energy every year can reduce the number of households do not have electricity and increase the number of households has electricity. The Simulation of household decline has no electricity and an increase in the number of households had electricity is shown in Fig. 4.

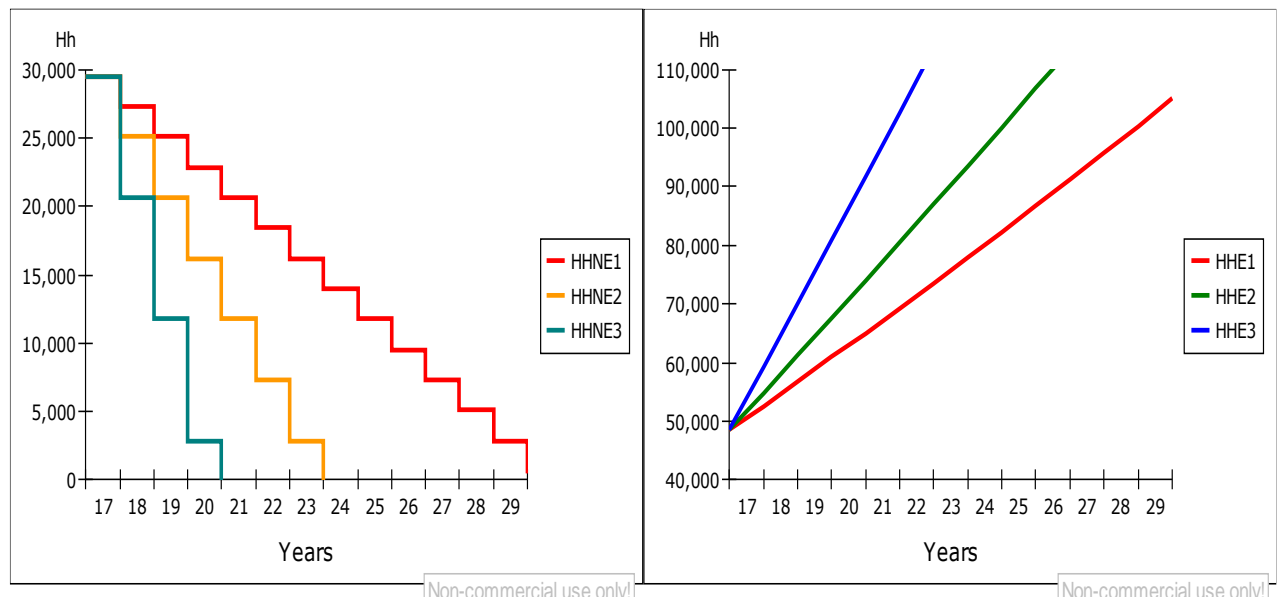

Figure 4. Simulation of household decline has no electricity and an increase in the number of households had electricity 


\section{CONCLUSION}

Electrification ratio can be achieved optimum estimated in 2020-2021 if the addition of capable power each year $4,000 \mathrm{~kW}$. The addition of capable power $2,000 \mathrm{~kW} /$ year, can reach the optimum electrification ratio in 2023-2024 and if the addition of capable power is only $1,000 \mathrm{~kW} /$ year, the optimum electrification ratio can be achieved in 2030-2031. $\mathrm{CO}_{2}$ emission reduction factor with diversified model of PLTD to PLTS is 2.46 Ton / $\mathrm{kW} /$ Year

\section{REFERENCES}

[1] Novakovic and A. Nasiri, Introduction to electrical energy systems. Electrical Engineering and Computer Science Department, College of Engineering and Applied Sciences, University of Wisconsin-Milwaukee, USA. Elsevier Inc. 1, 20 (2016)

[2] Perusahaan Listrik Negara. Statistik PLN. Jakarta. Sekretariat PT. PLN (PERSERO). 1 (2015)

[3] Badan Pusat Statistik. Kabupaten Kupang Dalam Angka. Kupang: Badan Pusat Statistik Kabupaten Kupang. 1 (2015)

[4] Pusat Data dan Teknologi Informasi Energi dan Sumberdaya Mineral. Data Inventory Emisi GRK Sektor Energi. Jakarta. Pusat Data dan T I ESDM. 1 (2015)

[5] Undang-Undang Republik Indonesia Nomor 16. Paris Agreement to the United Nations Framework Convention on Climate Change. Kementerian Hukum dan HAM. 1 (2016)

[6] Rahardjo I, Fitriana I. Analisis Potensi Pembangkit Listrik Tenaga Surya di Indonesia. P3TKKE, BPPT. 11, 43-52 (2015).

[7] Sinaga R. 2011. Pengaruh Parameter Lingkungan dan Penempatan Posisi Modul Terhadap Luaran Energi PLTS Menggunakan Solar Cell 50 Wp 12 Volt. Jurnal Studia Teknologia. 4 (2):110-120

[8] Tao Z, Liu Z, Changxin Z. 2011. Research on The Prospects of Low-Carbon Economic Development in China Based on LEAP Model. Energy Procedia. 5, 695699

[9] McPherson M, Bryan K. Long-Term Scenario Alternatives and Their Implications: LEAP Model Application of Panama's Electricity Sector. Energy Policy. 68, 146-157 (2014)

[10] Debnath KB, Mourshed M, Chew SPK. Modelling and forecasting energy demand in rural households of Bangladesh. Energy Procedia. 75, $731-737$ (2015)

[11] Parkinson SC, Djilali N. Long Term Energy Planning With Uncertain Environmental Performance Metrics. Applied Energy. 147, 402-412 (2015)

[12] Sugiyono A. Peran PLTN dalam Mendukung Komitmen Pemerintah untuk Mengurangi Emisi $\mathrm{CO}_{2}$. Prosiding Seminar Pengembangan Energi Nuklir Tahun 2010, PPEN BATAN. 1,199 (2010)

[13] Didit W. Analisis Pembangkit Listrik Tenaga Biogas Dengan Pemanfaatan Kotoran Sapi di Kawasan Usaha Peternakan Sapi. Master thesis. UI. 103 (2011)

[14] Sherwani AF, Usmani JA, Varun. Life Cycle Assesment of Solar PV Based Electricity Generation System: A Review. Renewable and Sustainable Energy Reviews.14, 540$544(2010)$

[15] United Nation Development Program. Indonesia: Microturbine Cogeneration Technology Application Project. Jakarta. UNDP. 95 (2007)

[16] DJK. Statistik Keteagalistrikan. Kementerian Energi dan Sumberdaya Mineral (2016)

[17] BPS. Amabi Oefeto Dalam Angka. Badan Pusat Statistik Kab. Kupang. (2016) 
[18] BPS. Amarasi Dalam Angka. Badan Pusat Statistik Kab. Kupang. (2016)

[19] BPS. Amarasi Selatan Dalam Angka. Badan Pusat Statistik Kab. Kupang. (2016)

[20] BPS. Amarasi Barat Dalam Angka. Badan Pusat Statistik Kab. Kupang. (2016)

[21] BPS. Amfoang Barat Daya Dalam Angka. Badan Pusat Statistik Kab. Kupang. (2016)

[22] BPS. Amfoang Barat Laut Dalam Angka. Badan Pusat Statistik Kab. Kupang. (2016)

[23] BPS. Amfoang Selatan Dalam Angka. Badan Pusat Statistik Kab. Kupang. (2016)

[24] BPS. Amfoang Timur Dalam Angka. Badan Pusat Statistik Kab. Kupang. (2016)

[25] BPS. Amabi Oefeto Timur Dalam Angka. Badan Pusat Statistik Kab. Kupang. (2016)

[26] BPS. Amfoang Tengah Dalam Angka. Badan Pusat Statistik Kab. Kupang. (2016)

[27] BPS. Amarasi Timur Dalam Angka. Badan Pusat Statistik Kab. Kupang. (2016)

[28] BPS. Amfoang Utara Dalam Angka. Badan Pusat Statistik Kab. Kupang. (2016)

[29] BPS. Fatuleu Tengah Dalam Angka. Badan Pusat Statistik Kab. Kupang. (2016)

[30] BPS. Fatuleu Barat Dalam Angka. Badan Pusat Statistik Kab. Kupang. (2016)

[31] BPS. Fatuleu Dalam Angka.Badan Pusat Statistik Kab. Kupang. (2016)

[32] BPS. Kupang Barat Dalam Angka. Badan Pusat Statistik Kab. Kupang. (2016)

[33] BPS. Kapang Tengah Dalam Angka. Badan Pusat Statistik Kab. Kupang. (2016)

[34] BPS. Kupang Timur Dalam Angka. Badan Pusat Statistik Kab. Kupang. (2016)

[35] BPS. Nekamese Dalam Angka. Badan Pusat Statistik Kab. Kupang. (2016)

[36] BPS. Semau Dalam Angka. Badan Pusat Statistik Kab. Kupang. (2016)

[37] BPS. Semau Selatan Dalam Angka. Badan Pusat Statistik Kab. Kupang. (2016)

[38] BPS. Sulamu Dalam Angka 2016. Badan Pusat Statistik Kab. Kupang. (2016)

[39] BPS. Taebenu Dalam Angka 2016. Badan Pusat Statistik Kab. Kupang. (2016)

[40] BPS. Takari Dalam Angka 2016. Badan Pusat Statistik Kab. Kupang . (2016) 